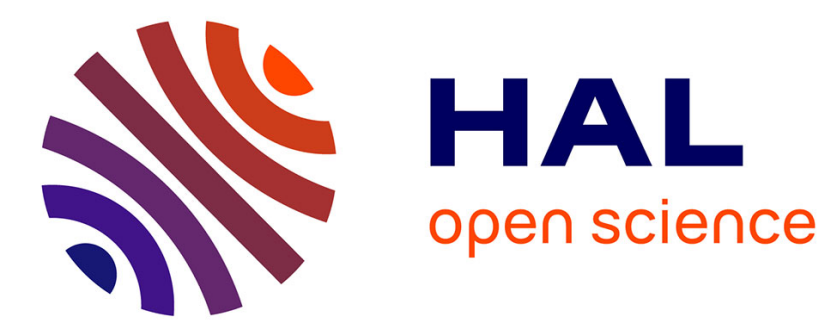

\title{
Prospects of applying 3-D printing to economics of remote communities
}

\author{
Svetlana V Obydenkova, Nicholas C Anzalone, Joshua M. Pearce
}

\section{To cite this version:}

Svetlana V Obydenkova, Nicholas C Anzalone, Joshua M. Pearce. Prospects of applying 3-D printing to economics of remote communities. Journal of Enterprising Communities: People and Places in the Global Economy, 2018, 12 (4), pp.488-509. 10.1108/JEC-08-2016-0029 . hal-02111367

\section{HAL Id: hal-02111367 https://hal.science/hal-02111367}

Submitted on 26 Apr 2019

HAL is a multi-disciplinary open access archive for the deposit and dissemination of scientific research documents, whether they are published or not. The documents may come from teaching and research institutions in France or abroad, or from public or private research centers.
L'archive ouverte pluridisciplinaire HAL, est destinée au dépôt et à la diffusion de documents scientifiques de niveau recherche, publiés ou non, émanant des établissements d'enseignement et de recherche français ou étrangers, des laboratoires publics ou privés. 
Preprint: Svetlana Obydenkova, Nicholas C. Anzalone, Joshua M. Pearce, (2018) "Prospects of applying 3-D printing to economics of remote communities: Reindeer herder case", Journal of Enterprising Communities: People and Places in the Global Economy, https://doi.org/10.1108/JEC-08-2016-0029

\title{
Prospects of applying 3-D printing to economics of remote communities:
}

\section{reindeer herder case}

Svetlana V. Obydenkova ${ }^{1}$, Nicholas C. Anzalone ${ }^{2}$ and Joshua M. Pearce ${ }^{3,4, *}$

1. School of Industrial Engineering and Management (ITM), Department of Energy Technology, KTH Royal Institute of Technology

2. Department of Mechanical Engineering-Engineering Mechanics, Michigan Technological University

3. Department of Materials Science \& Engineering, Michigan Technological University

4. Department of Electrical \& Computer Engineering, Michigan Technological University

* Corresponding author: 1400 Townsend Drive, Houghton, MI 49931-1295, pearce@mtu.edu

\begin{abstract}
Purpose - Isolated communities face a variety of inconveniences including severe remoteness, poor roads, extreme climate conditions, resulting in the lack of security of supply chains and exorbitant prices for cargo delivery. The paper investigates the present advantages and prospects of applying 3-D printing to improve economics and everyday life of remote communities, reindeer herder case taken as an example.
\end{abstract}

Design/Methodology/Approach - This study covers the use of a low-cost open-source 3-D printer (RepRap) capable of fused filament fabrication to reduce operating costs for nomadic reindeer herder groups. Three case studies are provided for reindeer specific applications to probe economic and technical viability of the technology, namely: ear tags, electric fence components and lasso accessories.

Findings -3-D printed objects feature technical characteristics similar to those of analogues available on the market while reducing the price by 63\%. Distributed 3-D printing reduces the cost of raw materials by $68 \%$ and shipping costs by $50 \%$ - due to lower trip frequency. If all reindeer herders globally were to adopt distributed manufacturing of the three aforementioned sample items only, their annual savings from such solution would amount to US\$ $2 \mathrm{mn}$. The paper discovers other economic, entrepreneurial, technical and environmental opportunities offered by 3-D printing put to service the needs of remote communities.

Practical implications - A valuable source of information for entrepreneurs, as well as for students and academics for further case-studies in this area.

Originality/Value - In remote conditions, 3-D printing offers a more sustainable way of good manufacturing. Numerous open source designs already available for specialists, financial effectiveness, environmental benefits, vast opportunities for entrepreneurs are among the most promising advantages of the technology. 
Keywords 3-D printing, distributed manufacturing, open-source hardware, community

\section{Introduction}

The release of the RepRap (self REPlicating RAPid prototyper) under open-source licenses has radically decreased the costs, while increasing the access to 3-D printers (Sells et al., 2009; Jones et al., 2011; Bowyer, 2014; Rundle, 2014). It has been shown that using a RepRap to fabricate end products can reduce costs for both high-end products like scientific equipment (Pearce, 2012; 2013; Wijnen et al., 2014; Baden et al. 2015; Wittbrodt et al., 2015) and for conventional mass-manufactured consumer goods (Gershenfeld, 2005; Bradshaw et al., 2010; Wittbrodt et al., 2013; Wohlers, 2014). The number of open source designs of all types has been rising exponentially (Wittbrodt et al., 2013), which increases the value for the printers for owners. Several studies have indicated that 3-D printers would also be useful for sustainable development (Pearce et al., 2010; Birtchnell and Hoyle, 2014; Ishengoma and Mtaho, 2014). These applications have focused primarily on issues related to communities in warm climates in the global south. For example, most small farmers in the developing world use labor-intensive agricultural hand tools and there has been some indications that superior tools can be developed and 3-D printed improving the efficiency of agriculture in the developing world (Ishengoma and Mtaho, 2014) and recent developments have indicated this could be happening (Pearce, 2015).

However, northern groups of indigenous people who live as nomadic reindeer herders face a variety of inconveniences, namely the dramatic remoteness of herders' camps from industrial centers, poor roads or even the full absence of them, extreme climate conditions, a difficult landscape and low population density in the regions where reindeer husbandry takes place. Therefore, they might experience dire challenges related to the lack of security in supply chains (Solvang and Hakam, 2010) and exorbitant prices for cargo delivery (Yu et al., 2014; Hageback and Segerstedt, 2004). Research in distributed manufacturing with solar-powered RepRaps (King et al., 2014) has shown that isolated communities are capable of making an assortment of products for themselves on location (Gwamuri et al., 2014; Khan et al., 2015).

This study investigates the viability and prospects of low-cost open-source 3-D printer capable of fused filament fabrication (FFF) plastic manufacturing to reduce the operating costs for nomadic reindeer herders as the example of the development of 3-D printing for rural application. It is assumed that reindeer herders can make use of the more than million open source designs for common consumer items just as any consumer might, however, here three case studies are provided (ear tag, electric fence components, and lasso accessory) for reindeer specific applications to probe the economic and technical viability of adopting this technology in nomadic northern communities. The economic evaluation has been prepared based on retailer prices for raw materials and the 3-D printer model, available literature data on reindeer husbandry and incumbent logistics data. 


\section{Literature review}

\section{Reindeer husbandry and indigenous communities}

Reindeer herding is a unique lifestyle featuring a basically nomadic existence spread remotely into the northern hemisphere and, quite often, in areas with extreme climate conditions (The International Center for Reindeer Husbandry; UN). Reindeer husbandry is typical for the northern groups of indigenous people who have developed this business over centuries, and constitutes the main part of income for such communities (Filppa, 2005; Tyler et al., 2007; Dana, 2008). Since such indigenous communities rely to a large extent on reindeer meat, milk and hides in their everyday life, their prosperity depends essentially on livestock well-being, and husbandry traditions are linked inherently to the local culture (Filppa, 2005; Dana, 2008; Roturier and Roué, 2009; Dana and Riseth, 2011, 2012). Nonetheless, at the same time, northern indigenous communities are able to successfully adopt innovations (Dana, 2008; Obydenkova and Pearce, 2016). The profound interaction of business and culture was found to be common also for northern rural settlements featuring activities other than reindeer husbandry such as fishing (Holen, 2009).

In spite of discernible community self-sufficiency in terms of natural food supply, there is still a demand for externally made goods for businesses or for other community needs. However, under the dramatic remoteness and extreme natural conditions found where these communities live, this can result in exorbitant fuel costs for transportation being added on to the cost of goods (Usher et al., 1994; Obydenkova and Pearce, 2016).

Personal income of a reindeer herdsman is relatively low (Jernsletten and Klokov, 2002; Reinert, 2006; Tyler et al., 2007; Dana and Light, 2011), as the herder needs to invest significant part of the family income into technical tool purchases and maintenance, as well as into transportation costs. The latter can become a major issue in severe northern conditions and, is observed quite often, in a mountainous territory (Jernsletten and Klokov, 2002; Yu et al., 2014). Therefore, herders might be interested in a new business model allowing them to obtain high-demand items at request and for a lower price, and on terms that do not compromise their cultural identity. Such a model may become possible via the involvement of distributed manufacturing with 3-D printing (Laplume et al. 2016).

Due to a variety of pre-conditions, modern reindeer husbandry has unique features, including those related to the business model applied, social, demographic and entrepreneurial specialties and culture. Husbandry can involve both indigenous people, like Sámi, Evenki, Nenets, Khanty, etc., and other nationalities irrelevant to indigenous people that can make difference in the approach towards business development. Traditionally, reindeer husbandry is a family or even a community-based business, several families uniting in small groups, co-operatives, crews or brigades (Filppa, 2005; Tyler et al., 2007; Dana and Riseth, 2011; UN). This feature, undoubtedly, adds a uniqueness to the entrepreneurial model applied (Ramadani and Hoy, 2015).

Although within such a unit livestock is officially owned by an individual herdsman, the herd is served and profit is shared between community members (Dana, 2008; Dana and Riseth, 2011; Dana and Riseth, 2012; UN). On the contrary, as it was found in the Finland case, non- 
indigenous reindeer owners behave more as conventional entrepreneurs (Dana and Riseth, 2011; Dana and Riseth, 2012).

For Russia, where the number of people potentially involved in reindeer husbandry and identified as indigenous, accounts for well over one hundred thousand individuals (The Russian national census, 2010), it was found common that women play the leading role in a community, becoming officially entrepreneur, i.e. the reindeers' legal owner, but still remaining in a profound connection with other community members. Nonetheless, in order to maintain community income women are often involved in other activities, e.g. carving, fur, clothes, felt, handicraft and jewelry manufacturing (Dana and Riseth, 2011; UN).

As opposed to a consensual view, rural communities generally feature necessary prerequisites for the development of entrepreneurship (Williams, 2011), e.g. some reindeer herder groups have been practicing agricultural trade for a long time (Reinert, 2006; Mason et al., 2012). However, to prove its success, the business model will require a thorough analysis of community entrepreneurial features that could be accomplished via quantitative and / or qualitative, or a socalled comprehensive research, where, among others, holistic inductive strategy, supplementing quantitative methods, will benefit for the better understanding of local entrepreneurship opportunities (Dana and Dana, 2005; Dana and Dumez, 2015). The latter originate from the evaluation of the entrepreneur nature and its close connections with culture and environment (Dana and Dana, 2005). To this end, Dana and Dana (2005) indicated that completing a case study would be useful for the consideration of different aspects of entrepreneurial environment.

\section{RepRap 3-D printing}

3-D printers are based on the principle of additive manufacturing and can use a variety of materials, such as polymers, ceramics and metals, among which the open source RepRap polymer-based 3-D printer has become the most popular (Pearce, 2013; Wohlers and Caffrey, 2014).

A RepRap 3-D printer works by pushing plastic filament (generally $3 \mathrm{~mm}$ or $1.75 \mathrm{~mm}$ in diameter) through an extruder, melting it and depositing a 2-D pattern on the substrate. The extruder is then moved up a fraction of a millimeter (normally $0.10 \mathrm{~mm}-0.35 \mathrm{~mm}$ ) and the next layer of the 3-D printed object is deposited. The process repeats until the entire object has been fabricated. There are many RepRap derivatives freely available on the internet (RepRap.org) that can be built for a small investment. For example, the MOST Delta RepRap costs under \$450 in parts and can be built in approximately eight hours once the bill of materials has been collected (Irwin et al., 2014; MOST, 2015). There are also commercially available RepRaps (such as the Lulzbot Taz), which can also be upgraded by printing replacement parts. Polylactic acid (PLA) used as raw material for RepRap features strong biodegradable and recyclable properties ( $\mathrm{Gu}$ and Catchmark, 2013; Kreiger and Pearce, 2013).

3-D printing has already come into common use (Wohlers and Caffrey, 2014): it has been put to work, for instance, in jewelry and spectacle manufacturing (Rayna and Striukova, 2016), and it was recognized to be advantageous for the sustainable development of rural communities based on small-scale organic agriculture (Pearce, 2015). 
As it was discussed earlier, indigenous communities are already applying a series of modern technologies in their everyday life, e.g. computers, GPS, etc. (Dana, 2008; Obydenkova and Pearce, 2016) that presumably means the readiness to furthermore adopt such disruptive innovation technologies as 3-D printing. Additionally, as it was shown, firms and entrepreneurs may benefit on the development of such technologies (Rayna and Striukova, 2016; GërguriRashiti et al., 2017).

\section{Methods}

\subsection{Equipment - RepRap 3-D Printers}

RepRaps are chosen for this study as reindeer herders, who are not only isolated for large portions of the year but are also generally handy at fixing equipment, would best be served by a 3-D printer they could maintain themselves. Having access to a machine that they can take apart, fix, upgrade and try their own modifications on provides far more value at a significantly lower cost than a conventional tooling arrangement with warranties and spare parts that simply not be available when transportation is eliminated (Yu et al., 2014). All of the MOST Delta RepRap design files, schematics, build instructions and bill of materials are available for free on Appropedia.org. To simply the economics it is assumed that the RepRaps will be powered with a solar photovoltaic and battery system following previously released open source designs (King et al., 2014; Khan et al., 2015). The cost of the electrical conversion in a high population center is approximately US\$600.

\subsection{Free and Open-Source Software}

All of the software necessary to design and operate RepRap 3-D printers is free and open source software that can be used for no costs. For reindeer herders seeking to minimize computing costs as well, older low-cost computers can be recycled into useful machines by installing a GNU/Linux (linux.com) based operating system such as Debian (debian.org). In addition, opensource computers such as the \$35 Raspberry Pi (raspberrypi.org) can be attached to recycled peripherals to operate the RepRap 3-D printer. Pi-top (Raspberry Pi powered laptop) can be purchased in kit form for $\$ 300$.

3-D digital designs can be created by reindeer herders themselves or customized from existing designs using OpenSCAD (openscad.org), which is a free and open-source script-based solid modeling program. OpenSCAD using parametric variables that automatically manipulate the entire part to enable simple modifications without the need for deep knowledge in 3-D modeling. Farmers that are comfortable with basic geometry can create complex designs by manipulating primitive shapes (e.g. spheres, cubes, cylinders). OpenSCAD then generates STL (STereoLithography) files of the finished parts, which are sliced with the open-source Cura (wiki.ultimaker.com/Cura) before printing. Parts that need structural strength are printed solid with $100 \%$ infill, while non-critical components can be printed with lower infills savings time, energy and plastic costs. Conventional RepRap firmware or the new Franklin printer firmware (Wijnen et al., 2015) was used on the printer itself. 


\subsection{Materials}

RepRaps typically print in polylactic acid (PLA) or acrylonitrile butadiene styrene (ABS), although many other polymer and even metal materials are possible. In this study PLA will be evaluated as it is a strong plastic - better than ABS, which for comparison is used to make Lego blocks (Tymrak et al., 2014). In a study of RepRap printed PLA the average tensile strengths ranged from 28.5 MPa for ABS and 56.6 MPa for PLA (Tymrak et al., 2014). PLA is a bio-based plastic made up a repeating chain of lactic acid and it is recyclable using conventional methods. In addition, PLA can be composted like other organic matter. The price of PLA is currently $\$ 15.52 / \mathrm{kg}$ on Ebay (Ebay, 2015). Transport and shipping fees to the tundra have been taken at the level of $\$ 11.69 / \mathrm{kg}$ of raw material.

The second material used was a flexible thermoplastic elastomer (TPE) type filament made of thermoplastic polyurethane under the tradename NinjaFlex. The TPE bonds directly to glass and prints at $210-225^{\circ} \mathrm{C}$ at $30 \mathrm{~mm} / \mathrm{s}$, which is slower than the stiffer thermoplastics. The price of ninjaflex is $\$ 31.57 / \mathrm{kg}$ (Sain Smart, 2015). Again the transport and shipping fees to the tundra have been taken at the level of $\$ 11.69 / \mathrm{kg}$.

\subsection{Case Study of Printable Objects}

Since the subsistence of most northern nomadic societies is crucially dependent on reindeer husbandry that contributes to the self-sufficiency of indigenous communities in the area of food supply, clothing, dwelling insulation, transportation, as well as in the community income, it is important to test the viability of 3-D printing for the manufacturing of goods needful for reindeer herding. For these purposes, three case studies of printable objects important for reindeer breeding have been selected: 1) ear tags, 2) electric fence components and 3) a reindeer lasso accessory.

\subsubsection{Ear tags}

Ear tags are unique color-coded labels attached to a reindeer's ear comprising a set of numbers that clearly indicate the animal's age and ownership (Godkin, 1986; Reindeer Husbandry Act, 1971; Andersen, 2011; Clarke and Dieterich, 1990), though other techniques for ownership identification still persist, such as making notches in calf ears, as it is used by some Sami people (Beach, 2007).

Usually, fawns are liable to tagging that is provided during the summer season, after calving. The number of calves is dependent on different factors (e.g. current economics, limits on livestock imposed by the authorities, etc.), however, under a stable environment, it must result directly from the number of reindeers owned by herders. Statistics given by (Filppa, 2005) indicates that, for instance, in Finland, from 1980 to 2004, the proportion of calves varied from 39.8\% $(1980 / 81)$ to $57.2 \%(2003 / 04)$ of the total amount of reindeers registered over the winter, while in Canada, in 1970s and 1980s, the number of yearly tagged fawns amounted to merely $23.4 \%$ (Godkin, 1986). Hence, the average rate of $36 \%$ of tagged fawns is approximated for the rest of countries (Table 1). 
The design of the 3D printed ear-tags was made using open source, script based 3-D CAD software (OpenSCAD). The design is dependent on a list of variables that can be changed to alter the design. Two lines of text were placed in the design that can be altered to make unique identifying numbers or names for each tag, and can be quickly changed through the use of the variables. The text is recessed into the ear tag, to facilitate 3-D printing and to prevent the text from becoming unreadable. The text is also scaled to the dimensions of the ear tag, which can also be altered by the variables. It is possible, through the altering of variables, to make many completely unique ear-tags from one file.

The ear tag design is divided into two components; the ear tag and the peg used to hold the ear tag in place. The ear tag was printed using TPE, a strong, flexible and durable polymer. The tag was printed with $35 \%$ of the interior volume is filled in order to make it lightweight and strong. The peg was printed using PLA, and was printed solid so as to make it as strong as possible.

Table 1. Yearly required number of ear-tags which can be manufactured by 3-D printing

\begin{tabular}{|c|c|c|c|c|}
\hline \multicolumn{2}{|c|}{ Country } & \multirow{2}{*}{\begin{tabular}{|l|}
$\begin{array}{c}\text { Number of } \\
\text { Reindeers }\end{array}$ \\
201,058
\end{tabular}} & \multirow{2}{*}{$\begin{array}{l}\begin{array}{c}\text { Rate of } \\
\text { calves, \% }\end{array} \\
48.5\end{array}$} & \multirow{2}{*}{$\begin{array}{c}\begin{array}{c}\text { Number of ear- } \\
\text { tags required } \\
\text { per year }\end{array} \\
97,513\end{array}$} \\
\hline Finland & (Filppa, 2005) & & & \\
\hline Canada & (Godkin, 1986) & 12,800 & 23.4 & 2,995 \\
\hline Sweden & (Moen, 2014) & 225,000 & \multirow[t]{6}{*}{36.0} & 81,000 \\
\hline Norway & (Sami Statistics, 2010) & 252,410 & & 90,868 \\
\hline Russia & (Baskin, 2005) & $1,200,000$ & & 432,000 \\
\hline $\begin{array}{l}\text { The United States } \\
\text { (Alaska) }\end{array}$ & $\begin{array}{l}\text { (Jernsletten and } \\
\text { Klokov, 2002) }\end{array}$ & 17,650 & & 6,354 \\
\hline Mongolia & \multirow{2}{*}{$\begin{array}{l}\text { (The International } \\
\text { Center for Reindeer } \\
\text { Husbandry) }\end{array}$} & 700 & & 252 \\
\hline China & & 1000 & & 360 \\
\hline \multicolumn{4}{|l|}{ Total } & 708,588 \\
\hline
\end{tabular}

The average retail price of manufactured ear-tags is US\$29 per bag of 23 (www.qcsupply.com, www.valleyvet.com) of US\$1.26 per tag. However, a low population density and the extreme remoteness of nomadic camps from any distribution or retailer center affect the good's price on site, which is substantially increased (Hageback and Segerstedt, 2004; Yu et al., 2014).

The Norwegian case (Solvang and Hakam, 2010) has been applied to calculate this surplus cost. Following this example, goods after having been delivered from Oslo to Narvik by train (that is about $250 \mathrm{~km}$ ), are distributed by trucks to the main centers such as Tromso located inside a traditional reindeer herding area Troms another $250 \mathrm{~km}$ away. In order to be delivered straight to the reindeer grazing areas (e.g. Kvaloy, Ringvassoy, Rebbnesoy, Northern Senja, etc. (Landbruksdirektoratet, 2015)), the goods are moved by smaller trucks and ferry across distances ranging from 13 to $230 \mathrm{~km}$. Hence, transportation surplus payment might be calculated assuming an average round-trip distance of $240 \mathrm{~km}$, a standard pickup to deliver ear-tags to an individual reindeer herding group, with gasoline consumption of about $14 \mathrm{~L} / 100 \mathrm{~km}$ and gasoline price of US\$1.878/L, as of July 1, 2015 (Statistics Norway, 2015; Bloomberg Business, 2015)). Since ear-tags are delivered once per year, for instance, before or during the calving period, the transportation surplus payment amounts to about US\$63.10 per one reindeer herding group. 
Annual expenses for manufactured ear-tags per one reindeer herding group by country are provided in Table 2, assuming a 20-year ear-tag lifespan that is equal to the life expectancy of a semi-domesticated reindeer, and given the use of one ear-tag per animal.

Table 2. Yearly herder group expenses for ear-tags

\begin{tabular}{|c|c|c|}
\hline \multirow[t]{2}{*}{ Country } & \multicolumn{2}{|c|}{$\begin{array}{c}\text { The Yearly Expenses for the Ear- } \\
\text { Tags, U.S. \$/year }{ }^{(a)}\end{array}$} \\
\hline & $\begin{array}{c}\text { By Reindeer } \\
\text { Herding Group }\end{array}$ & By Country \\
\hline Finland & 241 & 166,290 \\
\hline Norway & \multirow[t]{6}{*}{195} & 169,065 \\
\hline Sweden & & 150,735 \\
\hline Russia & & 804,920 \\
\hline The United States, Alaska & & 11,861 \\
\hline Mongolia & & 390 \\
\hline China & & 585 \\
\hline Canada & 149 & 6,556 \\
\hline & Total: & $1,310,402$ \\
\hline
\end{tabular}

\subsubsection{Electric fence components}

Due to a set of reasons, including those related to pastures size, rough landscape and the type of herding (i.e. so-called herd-following) (Anderson et al., 2014), regular winter and summer pastures are not fenced as a rule, with only several exceptions, such as, for instance, those observed in Finland where seasonal pastures are separated by grazing cycle fences (Reindeer Herders’ Association, 2014).

However, there are several cases, when the use of temporary fences during calving and postcalving time (i.e. in the summer season) is needed. Examples include: 1) to separate animals, i.e. milk females from the rest of the adults, 2) to protect fawns from predators, 3) to perform fawn tagging, or 4) to create shaded, smoke smudged pens, etc. (Reindeer Herders' Association, 2014; Anderson et al., 2014; Godkin, 1986). The length of such fences may reach up to dozens of kilometers (Reindeer Herders’' Association, 2014).

Those types of fences are expected to be lightweight and movable to provide an appropriate reindeer guide path that might be reached by the use of five-strand high tensile smooth wire electric fence (Fencing Factsheet, 1996).

The most plentiful set of plastic goods necessary to deploy electric fence are different types of insulators, which can be manufactured with the use of a 3-D printer (Table 3).

Table 3. Insulator specification for electric fencing according to (Fencing Factsheet, 1996)

\begin{tabular}{|l|l|}
\hline \multicolumn{1}{|c|}{ Material } & \multicolumn{1}{c|}{ Number per 1 km of Level Terrain } \\
\hline $\begin{array}{l}\text { Line insulators (nail or } \\
\text { screw onto post) }\end{array}$ & 328 \\
\hline Tie-off insulators & 12 (assuming at least 4 change of direction) \\
\hline
\end{tabular}


The potential yearly required number of insulators, provided in Table 4, is dependent directly on the number of reindeer in a herd and on the number of reindeer-herding groups. The Finnish case indicates that at least $10 \mathrm{~km}$ of temporary fences is deployed by each group (Reindeer Herders' Association, 2014). Actually, there are about 690 families practicing full-time reindeer husbandry (Filppa, 2005) that in fact represent reindeer-herding groups, and, hence, each group on average owns a herd of 291 species. Thus, the approach of calculating the load of a 3-D printer based on the number of reindeer in a herd belonging to an individual reindeer-herding group might be applied to the rest of countries where the exact number of herding groups is unknown (Table 4). A five-year insulator lifespan that is equal to warranty period provided by manufactures was assumed to evaluate annual demand for the articles.

Table 4. Yearly required number of insulators for electric fencing which can be manufactured by 3-D printing.

\begin{tabular}{|c|c|c|c|c|}
\hline \multirow[t]{2}{*}{ Country } & \multirow{2}{*}{$\begin{array}{l}\text { Number of } \\
\text { Reindeer- } \\
\text { Herding } \\
\text { Groups }\end{array}$} & \multicolumn{3}{|c|}{$\begin{array}{l}\text { Number of Insulators for Electric Fence } \\
\text { required per year (by country) }\end{array}$} \\
\hline & & Line insulators & $\begin{array}{c}\text { Tie-off } \\
\text { insulators }\end{array}$ & Total \\
\hline Finland & 690 & 452,640 & 16,560 & 469,200 \\
\hline Norway & 867 & 568,752 & 20,808 & 589,560 \\
\hline Sweden & 773 & 507,088 & 18,552 & 525,640 \\
\hline $\begin{array}{l}\text { The United States, } \\
\text { Alaska }\end{array}$ & 61 & 40,016 & 1,464 & 41,480 \\
\hline Mongolia & 2 & 1,312 & 48 & 1,360 \\
\hline China & 3 & 1,968 & 72 & 2,040 \\
\hline Russia & 4,124 & $2,705,344$ & 98,976 & $2,804,320$ \\
\hline Canada & 44 & 28,864 & 1,056 & 29,920 \\
\hline & Total: & $4,305,984$ & 157,536 & $4,463,520$ \\
\hline
\end{tabular}

The electric fence components were also designed using variables in OpenSCAD. Altering them allows the user to change all dimensions of the component, such as the wire retainer thickness and the diameter of the screw holes for attaching the component to a post. The component is printed in PLA and near solid (Around 80-90\% infill) to make it durable.

Annual expenses for purchase and delivery of insulators are provided in Table 5, assuming average purchase price on the market for line (nail or screw onto post) and tie-off insulators of US\$12 and \$US21 per bag of 50, respectively (www.maxflex.com, www.patriotchargers.com). The approach for the calculation of the additional cost of insulator delivery to a site is similar to that described in Section 2.4.1.

Table 5. Yearly expenses for electric fence insulators

\begin{tabular}{|l|c|c|}
\hline \multirow{2}{*}{ Country } & \multicolumn{2}{|c|}{$\begin{array}{c}\text { Yearly expenses for electric fence } \\
\text { insulators, U.S. \$/year }\end{array}$} \\
\cline { 2 - 3 } & $\begin{array}{c}\text { Ba) } \\
\text { By Reindeer } \\
\text { Herding } \\
\text { Group }\end{array}$ & By Country \\
\hline Finland & 230.6 & 159,114 \\
\hline Norway & & 199,930 \\
\hline Sweden & & 178,254 \\
& \multicolumn{2}{|c|}{9} \\
\hline
\end{tabular}




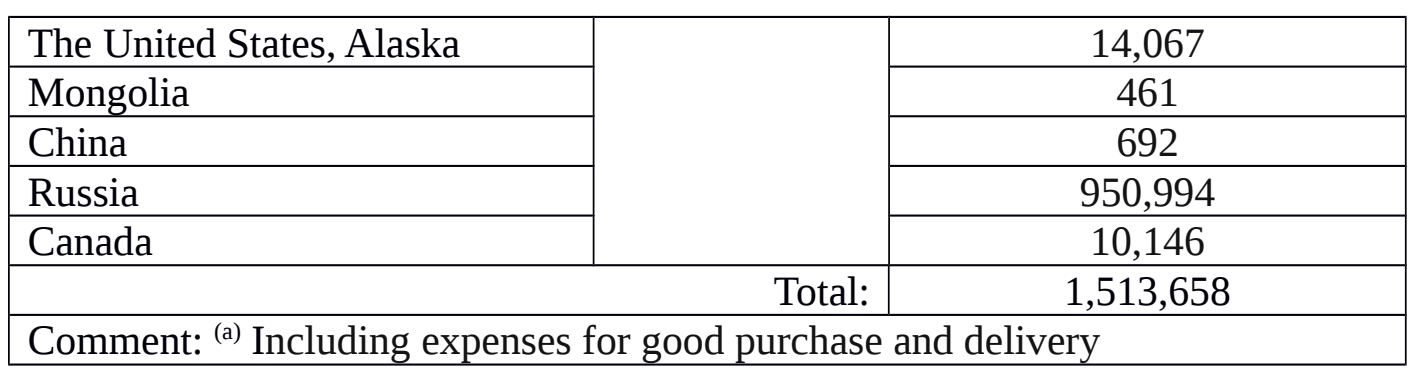

\subsubsection{Lasso Accessory}

Lassos are commonly used as reindeer herding tools to catch and hold a reindeer, and is comprised by a length of rope and a lasso accessory - a figure eight pattern (International Center for Reindeer Husbandry, 2015) or perforated plate, called a kielasta in Finnish. A few other terms in local languages are used sometimes to denote those objects. The accessories are necessary to create a noose which is set to be tightened around reindeer antler. Historically, they used to be made of bone or hartshorn, however due to the value of the materials involved in their manufacturing, other improvised substances have become more commonly utilized for that purpose. There is not too much information available on this matter, and from one indigenous community to another the mentioned accessory is different in size, weight and even in its shape. For instance, the figure-8 pattern made of hartshorn used in the Russian Amur Region has the following dimensions: $35 \mathrm{~mm}$ and $20 \mathrm{~mm}$ for the outer diameter, and $20 \mathrm{~mm}$ and $10 \mathrm{~mm}$ for the inner one (Fig. 1), and a little different form of the lasso accessory made of hartshorn by a Norwegian manufacturer is of $10 \mathrm{~cm}$ in length and weights $25 \mathrm{~g}$ (Duodjin, 2015).

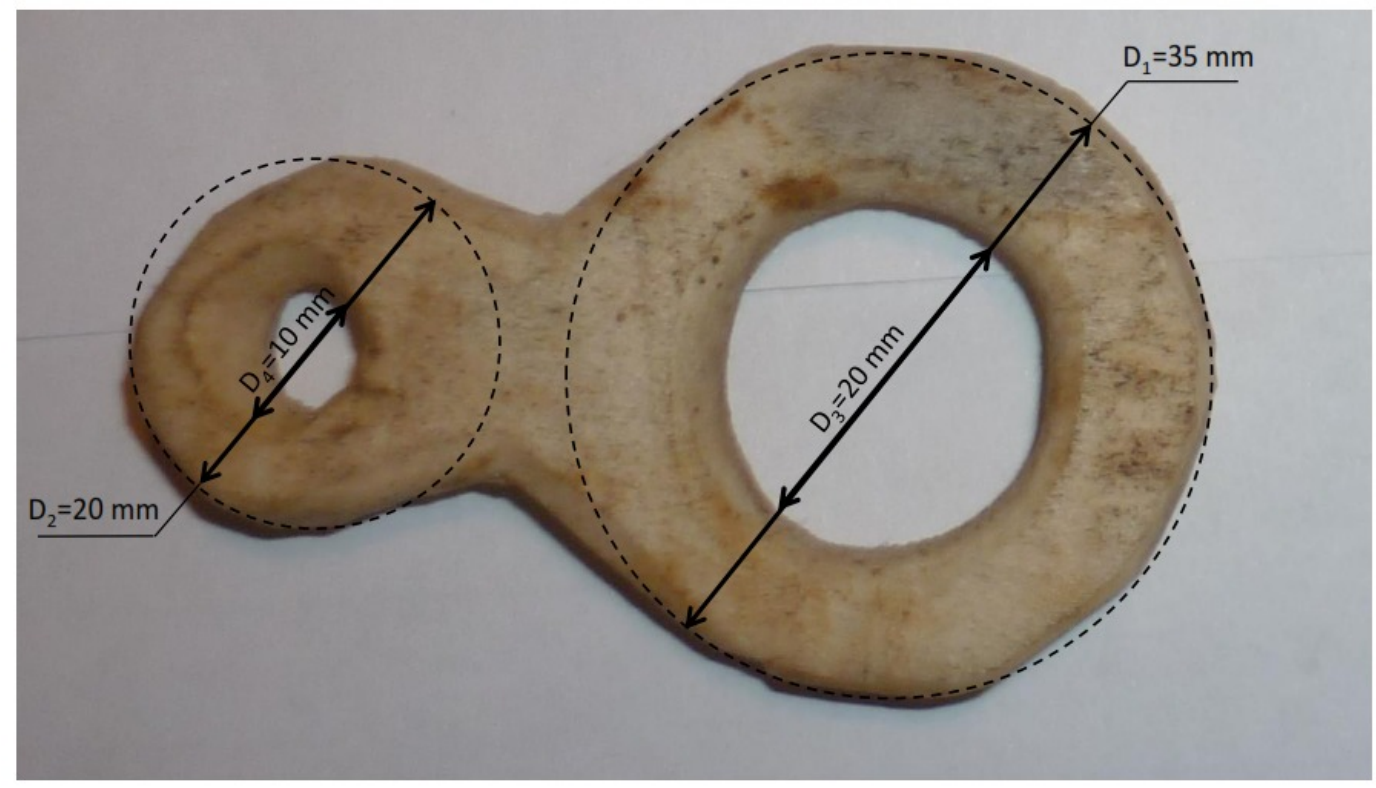

Fig.1. The figure-8 pattern made of hartshorn, manufactured by the Russian Evenks (outer diameters $\mathrm{D}_{1}$ and $\mathrm{D}_{2}$ are of 35 and $20 \mathrm{~mm}$, and inner diameters $\mathrm{D}_{3}$ and $\mathrm{D}_{4}$ are of 20 and $10 \mathrm{~mm}$, respectively.

Skills in lasso throwing along with the most successful lasso designs are revealed via herder competitions such as, for instance, World Reindeer Herders Lasso Championships (International Center for Reindeer Husbandry, 2015). The latter indicates the importance of lasso traditions for the reindeer husbandry culture. 
Given this, the current case study is of a design of printed plastic "Figure-8" lasso accessory, or kielasta. The number of lasso accessories used in each community might be evaluated assuming that every adolescent and every adult before the age of 69 practices lasso, and not only men, but also herdsmen's wives and even children learn and exercise the skills of throwing lasso at their duties, and especially in training at schools, as well as during herdsmen competitions (Table 6).

Table 6. Number of accessories for the lasso which can be manufactured by 3-D printing.

\begin{tabular}{|c|c|c|c|c|}
\hline \multicolumn{2}{|r|}{ Country } & \multirow{2}{*}{$\begin{array}{c}\text { Number of People } \\
\text { Potentially } \\
\text { Involved in } \\
\text { Reindeer } \\
\text { Husbandry } \\
5,344\end{array}$} & \multirow{2}{*}{ 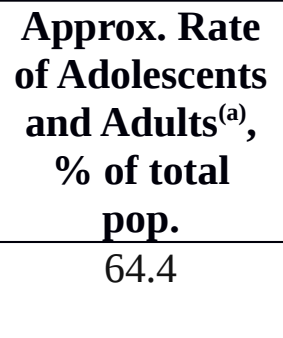 } & \multirow{2}{*}{$\begin{array}{l}\begin{array}{c}\text { Number of } \\
\text { the Lasso }\end{array} \\
\text { Accessories } \\
3,442\end{array}$} \\
\hline Finland & $\begin{array}{c}\text { (Filppa, 2005; Index } \\
\text { Mundi) }\end{array}$ & & & \\
\hline Norway & $\begin{array}{l}\text { (Sami statistics, 2010; } \\
\text { Sami in Sweden) }\end{array}$ & 57,500 & 74.7 & 42,953 \\
\hline Sweden & $\begin{array}{l}\text { (Sami in Sweden; Index } \\
\text { Mundi) }\end{array}$ & 30,000 & 63.2 & 18,960 \\
\hline $\begin{array}{l}\text { The United } \\
\text { States, Alaska }\end{array}$ & $\begin{array}{l}\text { (Jernsletten and } \\
\text { Klokov, 2002) }\end{array}$ & \multicolumn{2}{|c|}{$\begin{array}{l}150 \text { (number of people directly } \\
\text { involved in the reindeer husbandry) }\end{array}$} & 150 \\
\hline Mongolia & $\begin{array}{l}\text { (The International } \\
\text { Center for Reindeer } \\
\text { Husbandry; } \\
\text { Index Mundi) }\end{array}$ & 200 & 69.1 & 138 \\
\hline China & $\begin{array}{l}\text { (The International } \\
\text { Center for Reindeer } \\
\text { Husbandry; } \\
\text { Index Mundi) }\end{array}$ & 234 & 73.3 & 172 \\
\hline Russia & $\begin{array}{c}\text { (The Russian national } \\
\text { census, 2010) }\end{array}$ & 138,206 & 67.6 & 93,427 \\
\hline Canada & (Statistics Canada) & 3,668 & 75.0 & 2,751 \\
\hline \multicolumn{5}{|c|}{\begin{tabular}{lr|c} 
& Total: & 161,993 \\
Comment: & a) The figure refers to approx. rate of people between 15 (19 in some cases) and 69, \\
age groups of potential users of lasso.
\end{tabular}} \\
\hline
\end{tabular}

The lasso accessory was designed using variables in OpenSCAD. Altering the core variables allows the user to change all dimensions of the component to meet his or her needs for the specific type of rope for example. The component is printed in PLA and although it should have several outer complete layers can be printed with a smaller infill (e.g. 25\% infill) than the first two examples.

The lasso accessory made of hartshorn, according to data provided by a Norwegian retailer (Duodjin, 2015), costs about US\$53 for a bag of 23 or US\$2.30/per kielasta. Annual expenses for the lasso accessory are listed in Table 7, assuming a one year accessory durability. Since the lasso accessory might be manufactured by herders on site, the surplus cost of transportation is not taken into calculation.

Table 7. Yearly expenses for lasso accessory made of hartshorn 


\begin{tabular}{|l|l|l|}
\hline \multirow{2}{*}{ Country } & \multicolumn{2}{c|}{ Yearly expenses for lasso accessory, U.S. \$/year } \\
\cline { 2 - 3 } & \multicolumn{1}{|c|}{$\begin{array}{c}\text { by reindeer herding } \\
\text { group }\end{array}$} & \multicolumn{1}{c|}{ by country } \\
\hline Finland & 11.5 & 7,932 \\
\hline Norway & 114.2 & 98,979 \\
\hline Sweden & 56.5 & 43,690 \\
\hline $\begin{array}{l}\text { The United States, } \\
\text { Alaska }\end{array}$ & 5.7 & 346 \\
\hline Mongolia & 159 & 318 \\
\hline China & 132.1 & 396 \\
\hline Russia & 52.2 & 215,288 \\
\hline Canada & 144.1 & 6,339 \\
\hline \multicolumn{2}{|r|}{} \\
\hline
\end{tabular}

\section{Results}

\subsection{Ear-tags}

The ear tags were successfully fabricated with 3-D printing as shown in Figure 2.

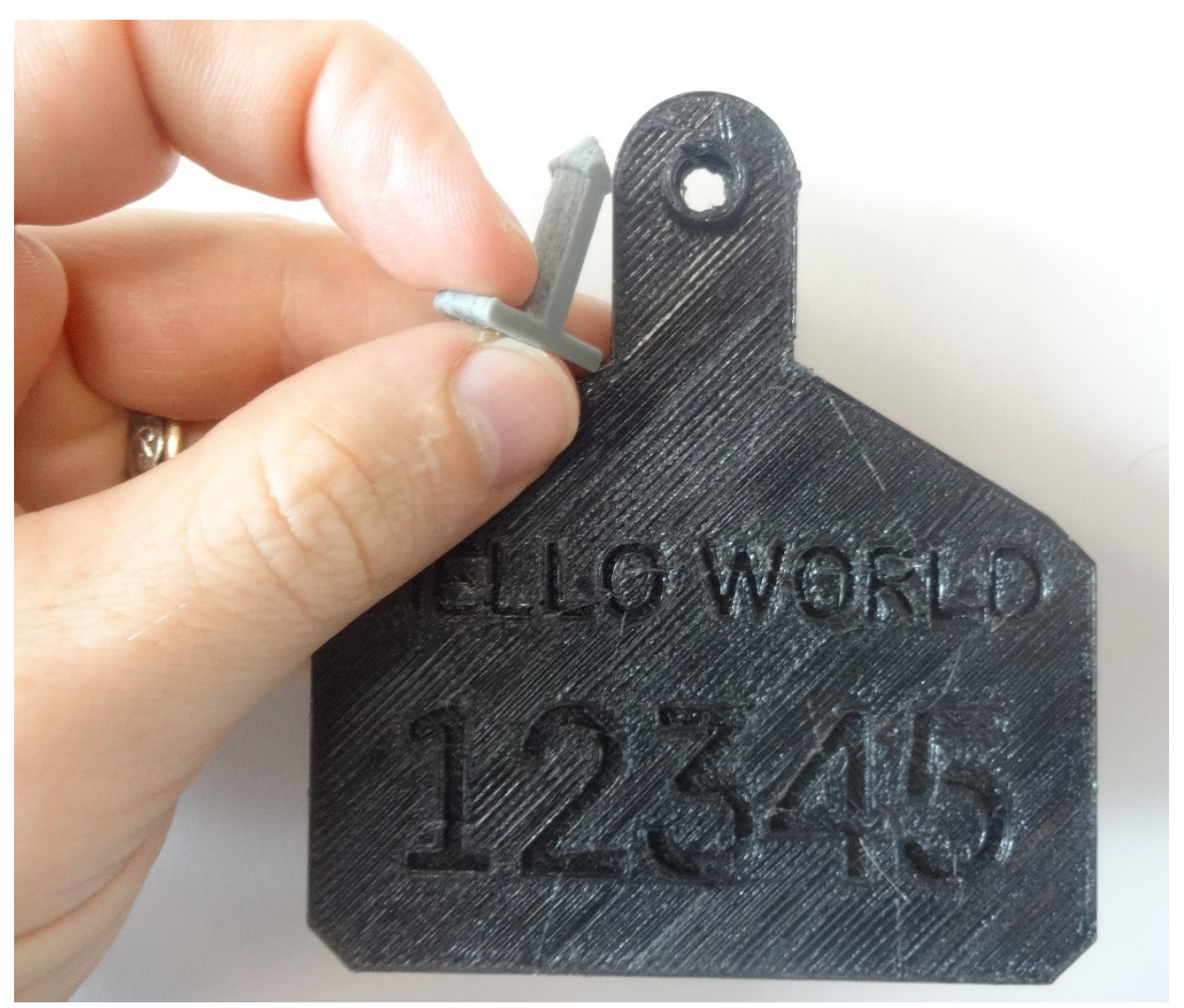

Figure 2. 3-D printed ear tag. PLA is in grey and ninjaflex in black.

Since all items considered in this study are lightweight with the total yearly average weight of all items per one reindeer group amounting to a mere $5.4 \mathrm{~kg}$, and are also produced from universal generic material, the feedstock of all items is supposed to be delivered by each group only once per year. To that end, in order to take into account surplus transportation payment for raw material delivery, the figure derived in Section 2.4.1, i.e. US \$63.10 per one trip, is used to get a specific value of US\$ 11.69 per kg of raw 3-D printing materials. 
Thus, the total potential annual savings arising from the use of 3-D printing for ear tags amounts to US \$ 742,115 globally (see Table 8).

Table 8. Saving estimates from distributed manufacturing of ear-tags, electric fence insulators and lasso accessories

\begin{tabular}{|c|c|c|c|c|c|c|c|}
\hline \multirow[t]{2}{*}{$\begin{array}{l}\text { Compone } \\
\text { nt }\end{array}$} & \multirow[t]{2}{*}{$\begin{array}{l}\text { Mas } \\
\text { s (g) }\end{array}$} & \multirow[t]{2}{*}{$\begin{array}{c}\text { Raw } \\
\text { Material cost } \\
\text { + Shipping } \\
\text { Cost } \\
\text { (US\$/kg) }\end{array}$} & \multicolumn{2}{|c|}{$\begin{array}{l}\text { Cost per } \\
\text { component } \\
\text { (US } \\
\text { \$/component) }\end{array}$} & \multicolumn{2}{|c|}{$\begin{array}{l}\text { Total Annual Cost for } \\
\text { all 3-D printed } \\
\text { manufactured case } \\
\text { study items }\end{array}$} & \multirow[t]{2}{*}{$\begin{array}{c}\text { Total } \\
\text { potential } \\
\text { annual } \\
\text { savings, } \\
\text { (US\$/year) }\end{array}$} \\
\hline & & & $\begin{array}{l}\text { Manuf } \\
\text { acturin } \\
\text { g }\end{array}$ & $\begin{array}{l}\text { Delive } \\
\text { ry }\end{array}$ & $\begin{array}{c}\text { for all } \\
\text { manufactu } \\
\text { red } \\
\text { articles, } \\
\text { (US\$/year) }\end{array}$ & $\begin{array}{c}\text { for raw } \\
\text { materials } \\
\text { delivery, } \\
\text { (US\$/year } \\
\text { ) }\end{array}$ & \\
\hline \multicolumn{8}{|c|}{ Ear-tag case study } \\
\hline Tag & 17.7 & $32+11.69$ & $\$ 0.57$ & $\$ 0.21$ & 403,895 & 148,803 & \multirow[t]{2}{*}{742,115} \\
\hline Plug & 0.8 & $15+11.69$ & $\$ 0.012$ & $\$ 0.01$ & 8,503 & 7,086 & \\
\hline \multicolumn{8}{|c|}{ Electric fence insulators case study } \\
\hline $\begin{array}{l}\text { Electric } \\
\text { insulator }\end{array}$ & 4 & $15+11.69$ & $\$ 0.06$ & $\$ 0.05$ & 267,811 & 223,176 & $1,022,671$ \\
\hline \multicolumn{8}{|c|}{ Lasso accessory case study } \\
\hline $\begin{array}{l}\text { Figure-8 } \\
\text { lasso } \\
\text { accessory }\end{array}$ & 27.3 & $15+11.69$ & $\$ 0.41$ & $\$ 0.32$ & 66,417 & 51,838 & 255,033 \\
\hline & & & & Total: & 746,626 & 430,903 & $2,019,819$ \\
\hline
\end{tabular}

\subsection{Electric Fence Components}

A parametric customizable electric fence component was successfully designed and printed in PLA, weighing $4 \mathrm{~g}$ as shown in Figure 3.

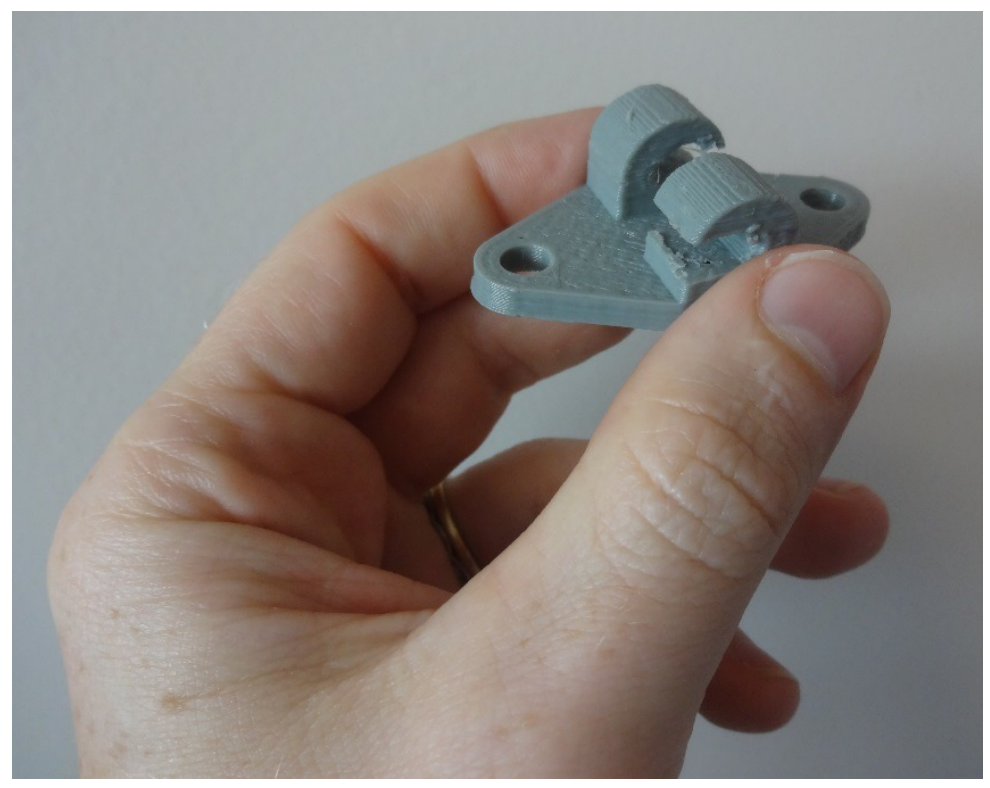

Figure 3. 3-D printed electric fence insulator. 
Potential economic savings from this case study have been calculated to be more than a million US dollars per year (Table 8).

\subsection{Lasso accessory}

A parametric customizable lasso accessory successfully 3-D printed. The exact weight will depend on the infill and the custom dimensions. Here the default printed in low-resolution on a TAZ-mini is 27.3g and is shown in Figure 4.

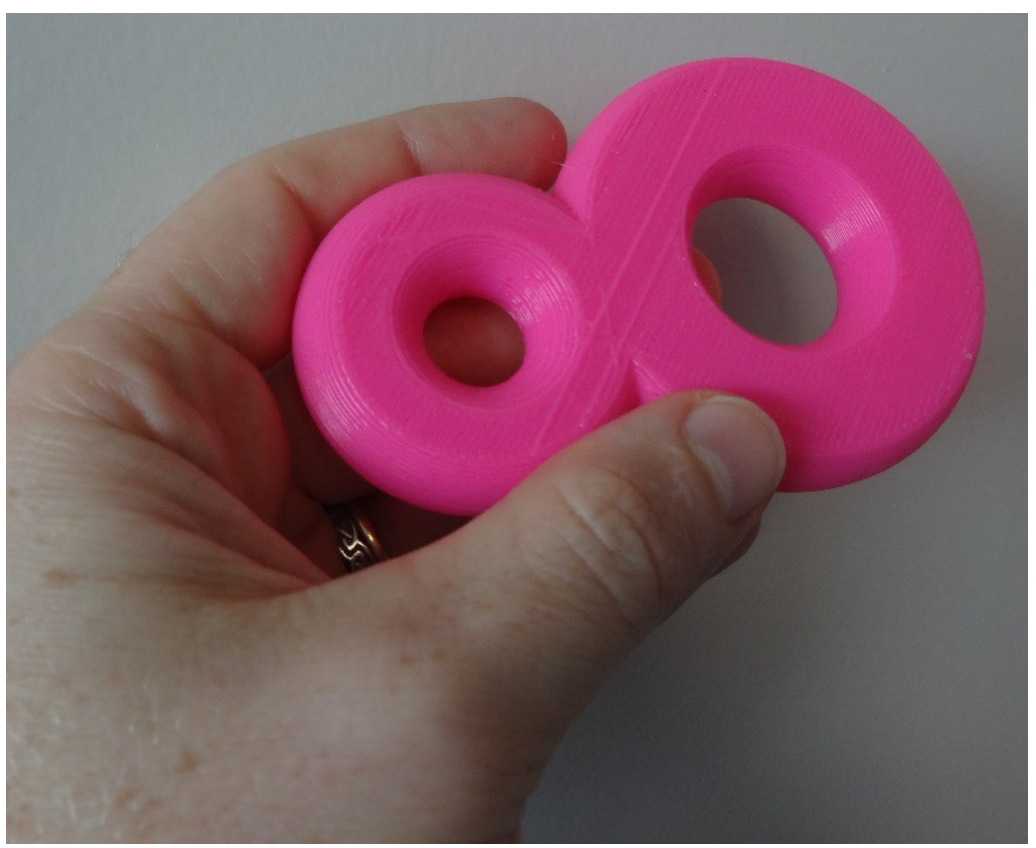

Figure 4. Lasso accessory - fully parametric and able to be customize, size and color.

The annual saving from the three object classes in the current case study amounts to US\$255,033 (Table 8).

One of the most important material properties of the objects is the accessory's tensile strength as it must withstand a material load when a reindeer is caught and held. The average tensile strength of PLA amounts to 56.6 MPa (Tymrak, 2014). Although the item made of compact dry antler bone is supposed to withstand higher loads: according to (Rajaram and Ramanathan, 1982), tensile strength of a wet and dry compact antler bone is $108 \pm 5.1$ and $188 \pm 12 \mathrm{MPa}$, respectively, the mechanical characteristics of PLA are in the same range as those of nylon and polyester, which lasso ropes are usually being made of indicating that the accessory should be adequately strong for this application. Made of PLA, the tool would be perfectly suitable for the application with the purposes of training.

\section{Discussion}

The implementation of 3-D printing technology for the local good manufacturing and its contribution to the development of reindeer herding communities should be considered from a number of aspects, namely from (i) economic and (ii) environmental point of view, (iii) 
mitigation of risks in the supply chain, (iv) development of entrepreneurship, and (v) taking into account other advanced features that become available due to the local 3-D printing manufacturing.

\section{(i) Economic means}

As it has been shown, the total price for the goods' manufacturing on-site with use of 3-D printing technology, including surplus transportation payment for raw material delivery, can be decreased by $63.2 \%$ compared to the cost of ready-made article purchase and delivery (see Figure 5). Price breakdown of $3-\mathrm{D}$ printed objects is as follows: $63.4 \%$ is the cost of raw materials and $36.6 \%$ is the shipping cost. The cost reduction is mainly due to manufacturing process, (decrease by 68.4\%), and lesser for surplus transportation payment, which is reduced with the use of 3-D printing by half, due to a decrease in the number of trips.

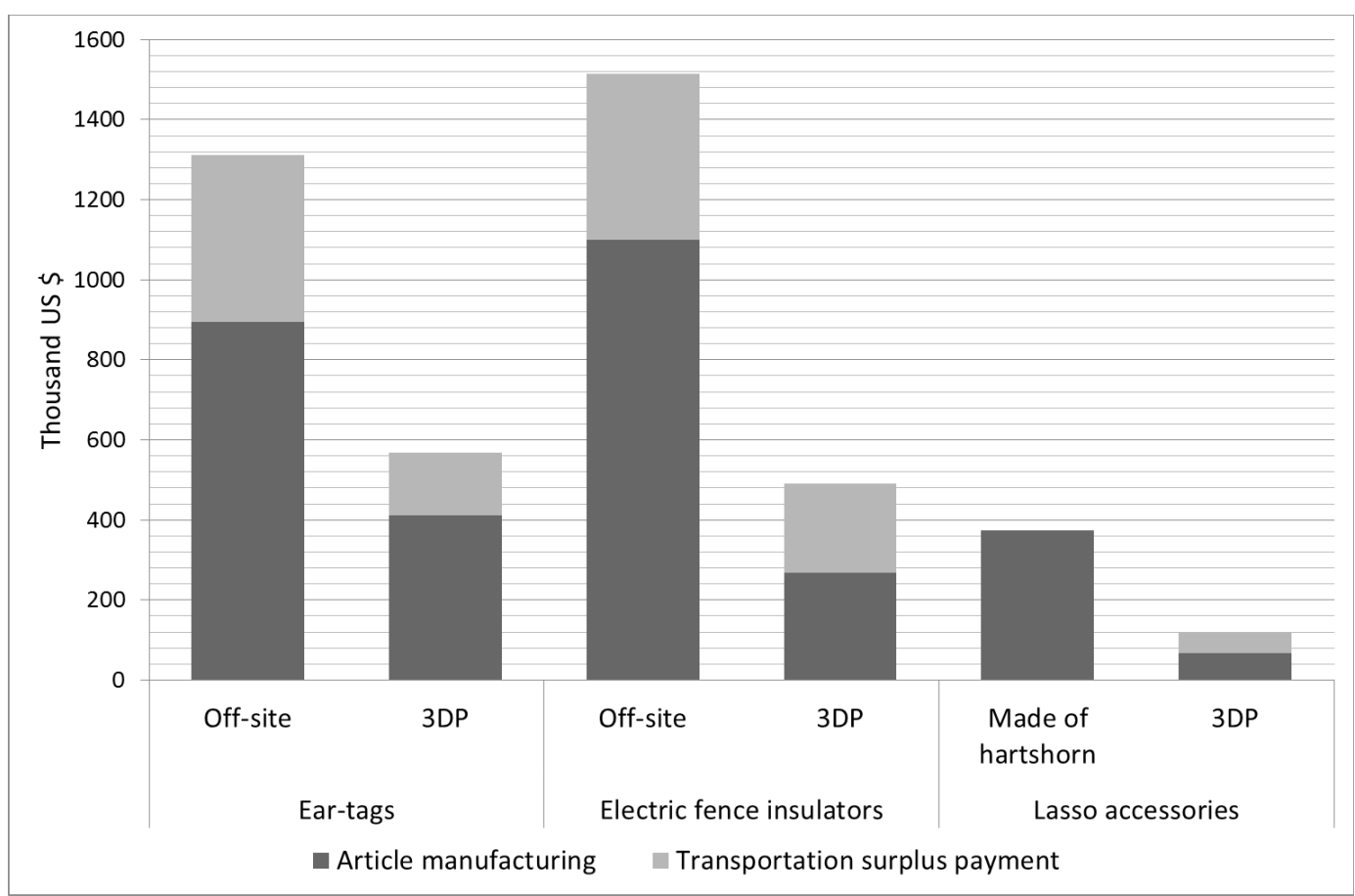

Figure 5. Total articles cost: manufactured off-site and on-site with use of 3-D printer

Thus, with the total annual saving from the project of over two million US dollars globally, the average saving per reindeer herding group would amount to US\$ 307.70 that, given only three types of 3D manufactured items utilized, would account for $1.6 \%$ of a herder's annual income, as it was reported by (Tyler et al., 2007).

Since one of the main goals of the project was to prove the viability of the local 3-D printing manufacturing, the economic evaluations as above consider only the most significant expenses and do not take into account such aspects as amortization, which actually can be applied for both 3-D printer ant vehicle, inflation, etc.

The simple payback period of the project for a community using LulzBot Mini 3D Printer that costs US\$1350 (www.lulzbot.com/catalog), a pi-top that costs US\$300 and the photovoltaic power for them both that costs US\$600 and keeping shipping cost at the level of at least $30 \%$ 
from the total sum, amounts roughly to 9.5 years. This is a positive high return on investment, but still a long time for a household to wait for a return. However, it must be pointed out that this simple payback is for only the three example items investigated here. There are more than a million open source 3-D printable objects already available on the web and previous students have shown that consumers can save substantial sums manufacturing their own products (Wittbrodt et al., 2014). Nevertheless, a more accurate calculation of the actual use and products printed by herders is needed to provide accurate project payback periods for this application.

Options for a further price reductions and value increases and, therefore, payback period reductions given the ample use of sustainable and economical distributed 3-D printing for herder needs may include the reutilization of wasted goods (Kreiger et al., 2014; Hunt et al., 2015), the delivery of a higher raw material load per one trip, and increasing workload for 3-D printer allowing more useful/valuable objects to be manufactured as it may be required.

Technical limitations arising for implementation of distributed 3-D printing technology into reindeer husbandry are mainly related to solar radiation conditions specific for sub-Arctic and Arctic regions. However, since, all the considered printable objects are required, mainly, during spring and summer seasons, when daily radiation reaches its maximal values (e.g. for northern part of Norway, up to $3.5 \mathrm{kWh} / \mathrm{m}^{2} /$ day in April and more than $5.5 \mathrm{kWh} / \mathrm{m}^{2} /$ day in June (NASA Atmospheric Science Data Center, 2015)), solar conditions might not be crucial for the project. Future experimental work is needed in the field to verify this potential.

\section{(ii) Environmental impact minimization}

PLA used for the item manufacturing refers to biodegradable nonhazardous materials produced from bio-sugar based sources (Gu and Catchmark, 2013). Kreiger and Pearce (2013) proved through conducting the life cycle analysis a sensible reduction of lifecycle GHG emissions for a set of items manufactured from PLA on-site using a RepRap printer coupled with solar photovoltaic arrays when compared to conventional manufacturing.

An additional environmental benefit can be expected from the reduction of cargo transportation that may turn out significant due to the dramatic remoteness of reindeer grazing areas, a difficult landscape and a low population density, resulting in the necessity for the individual delivery of goods. As it has been shown at the Norwegian case, an average cargo roundtrip from the nearest distribution center to the reindeer grazing area (i.e. for the individual reindeer herding group) amounts to $240 \mathrm{~km}$.

The amount of GHG originating from burning gasoline in vehicle engines can be calculated based on specific figures of emissions per a unit of distance driven, provided by the US Environmental Protection Agency for light-duty trucks featuring gasoline consumption of 0.14 $\mathrm{L} / \mathrm{km}$ (EPA, 2008).Thus, assuming that the introduction of 3-D printing for the local goods manufacturing allows to reduce freight traffic by at least $50 \%$, annual avoided $\mathrm{CO}_{2}$ tailpipe emissions can reach 0.077 tons per one herder's group and, globally, 0.5 to $1.1 \mathrm{kTCO}_{2}$ depending on the calculation of the number of herder groups worldwide. To compare, in $2008 \mathrm{CO}_{2}$ emissions originating from the US commercial light trucks amounted to 42.64 MMT (Greene et al., 2011). The latter figure may imply a great potential for the reduction of GHG emissions from the existing commercial transportation. A full life cycle analysis is needed to quantify the 
environmental impact reduction used for distributed manufacturing with 3-D printing in this context

\section{(iii) Mitigation of risks in supply chain}

Other obvious advantages that might be offered by the use of 3-D printing for the local goods manufacturing is the attainment of self-sufficiency in the supply chain, that as it was discussed can be of a serious concern for herders settled in mountain areas exposed to the extreme Arctic and sub-Arctic climate (Solvang and Hakam, 2010), and one of the main advantages of 3-D printing contributing to a more secure supply chain is its uniform raw material input. The latter feature implies that after 3-D printing introduction, the variety of products to be supplied to the site shrinks notably, allowing to develop a more efficient logistics for the supplies.

\section{(iv) Development of entrepreneurship}

As it was discussed in the literature review section, rural communities feature existing prerequisites for the development of entrepreneurship (Williams, 2011). Moreover, numerous studies supported by facts from our collaboration with northern indigenous communities have indicated at the willingness of those communities to develop other trading lines. For instance, on occasion, herder wives are creating and selling handicrafts, local footwear, clothes that in its turn feature different plastic details (e.g. beads) that can be fabricated with the use of a 3-D printer.

On the other hand, in spite of a gradual increase in the 3-D printer affordability, there is still a recognizable gap between local and household fabrication, where the first one refers to so called direct digital manufacturing where a business model implies that goods are printed at a community printshop_(Rayna and Striukova, 2016). However, the latter can be beneficial for herders, given that traditional reindeer husbandry, as it was discussed in the literature section, basically follows the community-based entrepreneurial model. Laplume et al. (2016) have also showed that at the current printer price the 3-D printing business model has become already viable and can offer essential profitability if a printer is set to serve community needs.

From the point of view of entrepreneurship development such performance would signify that a local entrepreneurs employing 3-D printing would be able to hike significantly their revenues from producing goods on-site and on request. This assumption becomes more plausible if a spectrum of applications where the use of 3-D printing technology has already proved its feasibility, e.g. for printing jewellery objects, spectacles (Rayna and Striukova, 2016), is considered.

As Smith (2012) indicated, “entrepreneurship is about effecting change”, that can be interpreted for an indigenous community practicing reindeer husbandry as a model of activity resulting in a higher community prosperity without compromising cultural values, the latter found of a very significant importance for those people. As it was discussed in the literature (Dana, 2008; Obydenkova and Pearce, 2016), reindeer herders already use a wide range of technological innovation and can be anticipated to continue to adopt new technologies in the future. The current case study has revealed the possibility to use printable on-site objects (e.g. ear-tags, fence insulators) instead of purchasing similar items for higher prices without damaging indigenous traditions. 


\section{(v) Other advanced features}

Several other advanced features related to the local goods manufacturing with the use of 3-D printing might be considered.

In the area of the local ear-tag manufacturing, the technology provides opportunities for an imminent addition to the label of other information that might be helpful for herding (e.g. sex and the most important medical records), allows to control the number of printed tags dependent on real birth rate data, and promotes the possibility of an urgent replacement of an ear-tag in the case of its damage or loss.

The use of temporary electric fences, that may become more realistic with local 3-D printing manufacturing of the plastic fence patterns (such as insulators and others), provide more efficient protection from predators such as wolves, bears, lynxes (Knipe, 1985) threatening both calves and adult reindeer (Anderson et al., 2014; Godkin, 1986; Sami Statistics, 2010; Tyler et al., 2007). This can be a significant benefit. For example, the yearly rate of calve losses in Finnmark and Norway reaches up to 30 - 65\% (Tyler et al., 2007). Moreover, since such types of fences are set to be used during the summer season, the installation can benefit from the use of solar photovoltaic technology as the source of power (NREL, 1997). To this point, Obydenkova and Pearce (2016), while investigating the feasibility of solar photovoltaics set to serve electric needs of herder nomadic camps in areas of reindeer husbandry deployment, showed the competitiveness of energy supply from photovoltaic compared to fuel-based systems.

The other obvious advantage of electric fences compared to the conventional wooden ones is a more modest demand for timber for fence construction, that otherwise may become an issue on remote locations, especially in tundra, and, additionally, a conventional fence might be up to ten times more expensive than electric one (Worley, 2015).

\section{Implications, future research and conclusions}

This paper considers the feasibility of 3-D printing technology to be used for the local good manufacturing for the needs of the reindeer herder society. Three case studies of 3-D printable objects have been explored: ear-tags, electric fence components and a reindeer lasso accessory. The articles were designed and printed with the use of the RepRap 3-D printers using free and open source software. All objects have been successfully printed and featured similar characteristics to those available on the market.

The results point at a potential significant reduction in prices for goods manufactured via 3-D printing on-site, by $63.2 \%$ in total, which is due to both lesser cost of manufacturing and reduced transportation costs. The cost of the latter is reduced by half, due to a decrease in the number of trips.

The total annual saving from the project amounts to over US\$ 2 million globally or, on the average basis, US\$ 307 per one reindeer herding group.

The investigation of other features of 3-D printing development trends that can benefit remote rural community has revealed opportunities for the mitigation of environmental impact, the 
development of entrepreneurship and the enhancement of agricultural practices, in reindeer husbandry in particular, without compromising the cultural identity of indigenous lifestyle.

The precise cases covered by this study represent a significant interest in terms of the project's further potential expansion, as reindeer husbandry is only one segment of farming, and hence those studies may be promising for many other farming segments from economic and environmental points of view.

It should be also noted that since the paper is the first-ever study of 3-D printing potential applied to the reindeer husbandry case, it is based on a more thorough analysis of the technoeconomic feasibility of the technology, while cultural and entrepreneurial factors have been discussed as preconditions only. Undoubtedly, in order to develop a successful business model, the latter requires an even more detailed investigation, especially with the involvement of a holistic-inductive research, as suggested by (Dana and Dana, 2005), that becomes increasingly important given cultural features intrinsic to such communities.

\section{References}

Anderson, D.G., Ineshin, E.M., Kulagina, N.V, Lavento, M. and Vinkovskaya, O.P. (2014), "Landscape agency and evenki-iakut reindeer husbandry along the Zhuia River, Eastern Siberia”, Human Ecology, Vol. 42, pp.249-266.

Andersen, O. (2011), "Reindeer-herding cultures in northern Nordland, Norway: Methods for documenting traces of reindeer herders in the landscape and for dating reindeer-herding activities”, Quaternary International, Vol. 238, pp.63-75.

Baden, T., Chagas, A. M., Gage, G., Marzullo, T., Prieto-Godino, L. L. and Euler, T. (2015), “Open Labware: 3-D Printing Your Own Lab Equipment”, PLOS Biology, Vol. 13 No.3, pp.1-12.

Baskin, L.M. (2005), "Number of wild and domestic reindeer in Russia in the late 20th century", Rangifer, Vol. 25, pp.51-57.

Beach, H. (2007), "Reindeer Ears: calf marking during the contemporary era of extensive herding in Swedish Saamiland". Annales Societatis Litterarum Humaniorum Regiae Upsaliensis, ISSN 0349-0416: 91-118, Online, available at: http://www.divaportal.org/smash/get/diva2:372620/FULLTEXT01.pdf (Accessed 15 September 2015).

Birtchnell, T. and Hoyle, W. (2014), “3D Printing for Development in the Global South: The 3D4D Challenge”. Palgrave Macmillan.

Bloomberg Business, Online, available at: http://www.bloomberg.com/quote/USDNOK:CUR (Accessed 14 September 2015).

Bowyer, A. (2014), “3D printing and humanity's first imperfect replicator”, 3D printing and additive manufacturing, Vol. 1 No.1, pp.4-5.

Bradshaw, S., Bowyer, A. and Haufe, P. (2010), “The intellectual property implications of lowcost 3D printing”. - ScriptEd Vol. 7 No.1, pp.5-31. 
Clarke, A. and Dieterich, R. (1990), “Record Keeping for Reindeer Herds”, Online, available at: http://reindeer.salrm.uaf.edu/resources/circulars/circular 75.pdf (Accessed 15 September 2015).

Dana, L. (2008), “Community-based entrepreneurship in Norway”, Int. Journal of Entrepreneurship and Innovation, Vol. 9 No.2, pp.77-92.

Dana, L. and Dana, T. (2005), "Expanding the scope of methodologies used in entrepreneurship research”, Int. Journal of Entrepreneurship and Small Business, Vol. 2 No.1, pp.79-88.

Dana, L. and Dumez, H. (2015), "Qualitative research revisited: epistemology of a comprehensive approach”, Int. Journal of Entrepreneurship and Small Business, Vol. 26 No.2, pp.154-170.

Dana, L. and Light, I. (2011), "Two forms of community entrepreneurship in Finland : Are there differences between Finnish and Sámi reindeer husbandry entrepreneurs?", Entrepreneurship \& Regional Development, Vol. 23, pp.331-352.

Dana, L. and Riseth, J. (2011), "Reindeer herders in Finland: Pulled to community-based entrepreneurship and pushed to individualistic firms”, The Polar Journal, Vol. 1 No.1, pp.108-123.

Dana, L. and Riseth, J. (2012), “Sámi reindeer herders in Finland: pulled to community-based entrepreneurship and pushed to individualistic firms”, In Entrepreneurship, Social Capital and Governance, pp.358-377.

Dana, L. \& Dumez, H., 2015. Qualitative research revisited: epistemology of a comprehensive approach. In international Journal of Entrepreneurship and Small Business. pp. 154-170.

Duodjin. Lasso ring / \&\#269;oarvegiella, Online, available at: http://duodjin.com/duodjin/index.php?main page=product info\&products id=72 (Accessed 4 September 2015).

Ebay, Online, available at: http://www.ebay.com/itm/like/261464565916? ul noapp=true\&chn=ps\&lpid=82 (Accessed 28 September 2015).

EPA. (2008), “Average Annual Emissions and Fuel Consumption for Gasoline-Fueled Passenger Cars and Light Trucks - Emission Facts” (EPA420-F-08-024), Online, available at: https://www3.epa.gov/otaq/consumer/420f08024.pdf (Accessed 10 August 2016).

Filppa, J. (2005) “Reindeer husbandry in Finland”, Rangifer, Vol. 25, pp.59-62.

Gershenfeld, N. (2005), Fab: The Coming Revolution on Your Desktop - from Personal Computers to Personal Fabrication, New York: Basic Books.

Godkin, G. (1986), “The reindeer industry in Canada”, Can Vet, Vol. 27 No. 12, pp.488-490.

Government of Canada. "Statistics Canada”, Online, available at: http://www.statcan.gc.ca/ (Accessed 15 July 2015).

Gërguri-Rashiti, S., Ramadani, V., Abazi-alili, H., Dana, L.and Ratten, V. (2017), "ICT, Innovation and Firm Performance: The Transition Economies Context”, Thunderbird International Business Review, Vol. 59 No.1, pp.93-102. 
Greene, D.L., Baker, H.H. and Plotkin, S.E. (2011), "Reducing Greenhouse Gas Emissions From U.S. Transportation”. Center For Climate and Energy Solutions.

Gu, J. and Catchmark, J.M. (2013), "Polylactic acid composites incorporating casein functionalized cellulose nanowhiskers”, Journal of Biological Engineering, Vol. 7, pp. 110.

Gwamuri, J., Wittbrodt, B. T., Anzalone, N. C. and Pearce, J.M. (2014), "Reversing the Trend of Large Scale and Centralization in Manufacturing: The Case of Distributed Manufacturing of Customizable 3-D-Printable Self-Adjustable Glasses”, Challenges in Sustainability, Vol. 2 No. 1, pp.30-40.

Hageback, C. and Segerstedt A. (2004), "The need for co-distribution in rural areas - a study of Pajala in Sweden”, International Journal Production Economics, Vol. 89, pp.153-63.

Holen, D. (2009), “The dynamic context of cultural and social sustainability of communities in Southwest Alaska”, Journal of Enterprising Communities: People and Places in the Global Economy, Vol. 3 No.3, pp.306-316.

Index Mundi. “Age distribution by country”, Online, available at: www.indexmundi.com (Accessed 31 August 2015).

International Center for Reindeer Husbandry, Online, available at: http://reindeerherding.org/ (Accessed 15 July 2015).

Irwin, J. L., Pearce, J. M., Anzolone, G., and Oppliger, D. E. (2014), “The RepRap 3-D Printer Revolution in STEM Education”, In: 121st ASEE Annual Conference \& Exposition, Online, available at: http://www.asee.org/file server/papers/attachment/file/0004/4989/asee reprap paper final1.pdf

Ishengoma, F. R. and Mtaho, A. B. (2014), “3D Printing: Developing Countries Perspectives”, arXiv preprint arXiv:1410.5349.

Jones, R., Haufe, P., Sells, E., Iravani, P., Olliver, V., Palmer, C. and Bowyer, A. (2011), “RepRap - the replicating rapid prototype”, Robotica, Vol. 29 No. 01, pp.177-191.

King, D.L., Babasola. A., Rozario, J. and Pearce, J.M. (2014), “Mobile Open-Source SolarPowered 3-D Printers for Distributed Manufacturing in Off-Grid Communities", Challenges in Sustainability, Vol. 2 No. 1, pp.18-27.

Khan, K.Y., Gauchia, L., and Pearce, J.M. (2015), "Self-Sufficiency of 3-D Printers: Utilizing Stand-alone Solar Photovoltaic Power Systems”, 3-D Printed Materials and Systems (in press).

Knipe, O.D. (1985), “Predator-Deterrent Electric Fence for Rough Terrain”, Rangelands, Vol. 7 No. 4, pp.148-153.

Kreiger, M.A. and Pearce, J.M. (2013), "Environmental Life Cycle Analysis of Distributed 3-D Printing and Conventional Manufacturing of Polymer Products", ACS Sustainable Chemistry \& Engineering, Engineering, Vol. 1 No. 12, pp.1511-1519.

Kreiger, M.A., Mulder, M.L., Glover, A.G. and Pearce, J.M. (2014), "Life cycle analysis of distributed recycling of post-consumer high density polyethylene for 3-D printing filament”, Journal of Cleaner Production, Vol. 70, pp.90-96.

Jernsletten, J.L. and Klokov, K. (2002), “Sustainable Reindeer Husbandry”. Arctic Council. 
Landbruksdirektoratet. (2013), “Reindeer herding in Troms”, Online, available at: www.reinddrift.no (Accessed 14 September 2015).

Laplume, A., Anzalone, G.C. and Pearce, J.M. (2016), “Open-source, self-replicating 3-D printer factory for small-business manufacturing”, The International Journal of Advanced Manufacturing Technology, Vol. 85, pp.633-42.

Mason, A.H.M., Anderson, R.B. and Dana, L-P. (2012), "Inuit culture and opportunity recognition for commercial caribou harvests in the bio economy”, Journal of Enterprising Communities: People and Places in Global Economy, Vol. 6 No 3, pp.194-212.

Ministry of Agriculture, Food and Fisheries. (1996), "Livestock Control. Electric fence design”, Fencing Factsheet, pp.1-10, Online, available at: http://www.agf.gov.bc.ca/resmgmt/publist/300Series/307260-2.pdf $\quad$ (Accessed 14 September 2015).

Moen, J. (2008), “Climate Change: Effects on the Ecological Basis for Reindeer Husbandry in Sweden” Ambio, Vol. 37 No. 4, pp.304-311.

MOST. (2014), Delta Build Overview: MOST Online, available at: http://www.appropedia.org/Delta Build Overview:MOST (Accessed 15 September 2015).

NASA Atmospheric Science Data Center, Online, available at: https://eosweb.larc.nasa.gov/cgibin/sse/grid.cgi?email=skip@larc.nasa.gov (Accessed 15 July 2015).

NREL. (1997), "Electricity when and where you need it: from the sun”, Online, available at: http://www.nrel.gov/docs/gen/fy97/21732.pdf (Accessed 5 October 2015).

Obydenkova, S.V., and Pearce, J.M. (2016), “Technical Viability of Mobile Solar Photovoltaic Systems for Indigenous Nomadic Communities in Northern Latitudes”, Renewable Energy Vol. 89, pp.253-267.

Pearce, J. M. (2012), “Building research equipment with free, open-source hardware”, Science, Vol. 337 No. 6100, pp.1303-1304.

Pearce, J. M. (2013), "Open-source lab: How to build your own hardware and reduce research costs”, Elsevier, New York.

Pearce, J.M. (2015), “Applications of Open Source 3-D Printing on Small Farms”, Organic Farming, Vol. 1 No. 1, pp.19-35.

Pearce, J. M., Blair, C. M., Laciak, K. J., Andrews, R., Nosrat, A. and Zelenika-Zovko, I. (2010), "3-D printing of open source appropriate technologies for self-directed sustainable development”, Journal of Sustainable Development, Vol. 3 No. 4, pp.17.

Rajaram, A. and Ramanathan, N. (1982), “Tensile Properties of Antler Bone”, Calcif Tissue Int, Vol. 34, pp.301-305.

Ramadani, V. and Hoy, F. (2015), “Context and Uniqueness of Family Businesses”, In L.-P. Dana and V. Ramadani, eds. Family Businesses in Transition Economies. pp. 9-37.

Rayna, T. and Striukova, L. (2016), "From rapid prototyping to home fabrication: How 3D printing is changing business model innovation", Technological Forecasting \& Social Change, Vol. 102, pp.214-224. 
Reindeer Husbandry Act. (1971), Sweden, Online, available at: http://www.notisum.se/Pub/Doc.aspx?url=/rnp/sls/lag/19710437.htm (Accessed 15 August 2015).

Reinert, E.S. (2006), “The economics of reindeer herding”, British Food Journal, Vol. 108 No 7, pp.522-540.

Rundle, G. (2014), “A Revolution in the Making”. Affirm Press; South Melbourne.

Russian National Census. (2010), Online, available at: http://www.gks.ru/free doc/new site/perepis2010/croc/perepis itogi1612.htm (Accessed 15 July 2015).

Roturier, S. and Roué, M. (2009), “Of forest, snow and lichen: Sámi reindeer herders’ knowledge of winter pastures in northern Sweden”, Forest Ecology and Management, Vol. 258 No.9, pp.1960-1967.

Sain Smart, Online, available at: http://www.sainsmart.com/sainsmart-1-75mm-1kg-2-2lbflexible-tpu-series-filament-for-3d-printers-reprap.html? gclid=CJuok56EmsgCFYk7aQodSfoEHA\&kpid=963 en (Accessed 28 September 2015).

Sami in Sweden, Online, available at: http://www.samer.se (Accessed 31 August 2015).

Sami Statistics. (2010), “Statistics Norway", Online, available at: http://www.ssb.no/a/english/publikasjoner/pdf/nos d443 en/nos d443 en.pdf (Accessed 31 August 2015).

Sells, E., Smith, Z., Bailard, S., Bowyer, A. and Olliver, V. (2009), "RepRap: The Replicating Rapid Prototyper: Maximizing Customizability by Breeding the Means of Production”, In Piller, F. T., Tseng, M. M. (Eds.). Handbook of Research in Mass Customization and Personalization: Strategies and concepts. World Scientific Vol 1, pp. 568-580, 2010.

Smith, R. (2012), "Developing and animating enterprising individuals and communitiesA case study from rural Aberdeenshire, Scotland", Journal of Enterprising Communities: People and Places in the Global Economy, Vol. 6 No.1 pp. 57 - 83.

Solvang, W.D. and Hakam, M.H. (2010), "Sustainable logistics networks in sparsely populated areas”, J. Service Science \& Management, Vol. 3, pp.72-77.

Statistics Norway. "Sales of petroleum products", Online, available at: https://www.ssb.no/statistikkbanken/selectvarval/Define.asp?

subjectcode=\&ProductId=\&MainTable=PetroleumSalg5\&nvl=\&PLanguage $=1 \& n y T m p V a$

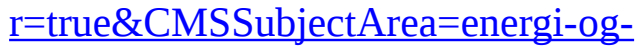

industri\&KortNavnWeb=petroleumsalg\&StatVariant=\&checked=true $\quad$ (Accessed 14 September 2015).

Tymrak, B. M., Kreiger, M. and Pearce, J. M. (2014), "Mechanical properties of components fabricated with open-source 3-D printers under realistic environmental conditions", Materials \& Design, Vol. 58, pp.242-246.

Tyler, N.J.C., Turi, J.M., Sundset, M.A., Strøm Bull, K., Sara, M.N., Reinert, E., Oskal, N., Nellemann, C., McCarthy, J.J., Mathiesen, S.D., Martello, M. L., Magga, O. H., Hovelsrud, G. K., Hanssen-Bauer, I., Eira, N.I., Eira, I.M.G. and Corell, R.W. (2007), "Saami reindeer pastoralism under climate change: Applying a generalized framework for vulnerability 
studies to a sub-arctic social-ecological system”, Global Environmental Change, Vol. 17, pp.191-206.

UN Educational, Scientific and Cultural Organization and UNESCO Institute of Information Technologies in Education Climate Change Adaptation. "Traditional Knowledge of Indigenous Peoples Inhabiting the Arctic and Far North”, Online, available at: http://iite.unesco.org/courses/climate change/en/index.html (Accessed July 12.01 2017).

Usher, E., Jean, G. and Howell, G. (1994), “The use of photovoltaics in a northern climate”, Solar Energy Materials and Solar Cells, Vol. 34 No.1-4, pp.73-81.

Wijnen, B., Anzalone, G.C. and Pearce, J.M. (2014), “Open-source mobile water quality testing platform”, Journal of Water, Sanitation and Hygiene for Development, Vol. 4 No. 3, pp.532-537.

Wijnen, B., Anzalone, G.C., Haselhuhn, A.S., Sanders, P.G. and Pearce, J.M. (2016), "Free and Open-source Control Software for 3-D Motion and Processing”, Journal of Open Research Software, Vol.4 No.1, p.e2.

Williams, C.C. (2011), "Entrepreneurship, the informal economy and rural communities" Journal of Enterprising Communities: People and Places in Global Economy, Vol. 5 No 2, pp.145-57.

Wittbrodt, B. T., Glover, A. G., Laureto, J., Anzalone, G. C., Oppliger, D., Irwin, J. L. and Pearce, J. M. (2013), "Life-cycle economic analysis of distributed manufacturing with open-source 3-D printers”, Mechatronics, Vol. 23 No. 6, pp.713-726.

Wittbrodt, B.T., Squires, D.A., Walbeck, J., Campbell, E., Campbell, W.H. and Pearce, J.M. (2015), “Open-Source Photometric System for Enzymatic Nitrate Quantification”, PLoS ONE, Vol. 10 No. 8, e0134989.

Wohlers, T. and Caffrey, T. (2014), “Wohlers Report 2014 Annual Worldwide Progress Report”. Wohlers Associates, Inc. Fort Collins, CO.

Worley, J.W. (2015), “Fences for the farm”. UGA Extension, Online, available at: http://extension.uga.edu/publications/files/pdf/C\%20774 5.PDF (Accessed 18 September 2015).

Yu, H., Solvang, W.D. and Chen, C. (2014), "A green supply chain network design model for enhancing competitiveness and sustainability of companies in high north arctic regions", International Journal of Energy and Environment, Vol. 5, pp.403-418. 